\title{
Congenital Nephrogenic Diabetes Insipidus in an Adult
}

\author{
Hajime IshiI, Kenji Mizuno, Susumu Nimmura, Hiroshi Haga, Michihiko Takahashi, Yukari Watanabe, \\ Kiyonobu Tanaka, Manabu Ogata*, Noboru TanaKA** and Soitsu Fukuchi
}

\begin{abstract}
A 35-year-old man with congenital nephrogenic diabetes insipidus (NDI) is reported. Renal biopsy revealed miniaturized and rounded mitochondria of the proximal tubular cells and decreased brush-borders. Trichlormethiazide combined with triamterene resulted in an apparent reduction of daily urine volume and concomitant increment in urine osmolarity. The present case seems rare in that some morphological changes in the renal tissues could be demonstrated in an adult case with congenital NDI.
\end{abstract}

(Internal Medicine 32: 133-138, 1993)

Key words: mitochondria, kidney biopsy, brush-border, trichlormethiazide, triamterene

\section{Introduction}

Nephrogenic diabetes insipidus (NDI) is a rare disease which is characterized by polydipsia and polyuria with low specific gravity. This disease is a renal tubular disorder characterized by inability of the distal and collecting tubules to concentrate urine despite the administration of pharmacologic doses of anti-diuretic hormone (ADH) (1).

Although NDI is generally transmitted as a sex-linked recessive disorder (2), sporadic cases have also been reported in both sexes $(3,4)$. An adult case of congenital NDI with no family history of this entity is reported.

\section{Case Report}

A 35-year-old Japanese man was admitted to our clinic because of severe polydipsia and polyuria. He was born on March 9, 1956, following a full-term pregnancy and normal delivery. He weighed $2,450 \mathrm{~g}$ at birth. At 2 months of age, 2-3 day episodes of spiking fever (about $40^{\circ} \mathrm{C}$ or more), frequent vomiting, and severe constipation began to occur. He was seen by a physician at that time, but symptoms were not improved. His mother noticed that these symptoms disappeared when she gave a great volume of milk and water. However, because of the persistence of these symptoms, he was admitted to another hospital at 6 years of age. But the cause of polydipsia and polyuria was not clarified. Polydipsia and polyuria were not treated during the hospital- ization or after discharge. He drank approximately 10 liters or more of water per day. He had no mental retardation and he was of average intelligence.

At age 35 years, he was admitted to a hospital because of severe sore throat and fever $\left(39^{\circ} \mathrm{C}\right)$. A diagnosis of purulent tonsillitis was made. At that time, a physician recognized an abnormal daily intake of water and polyuria, $10-151 /$ day. He was then admitted to our clinic for evaluation of polydipsia and polyuria on March 11, 1991.

Physical examination revealed a normally grown and nourished man. His height was $168.5 \mathrm{~cm}$, weight $58.5 \mathrm{~kg}$, temperature $36.3^{\circ} \mathrm{C}$, pulse rate 72 beats $/ \mathrm{min}$, regular, and blood pressure $124 / 70 \mathrm{mmHg}$. Lungs, heart, abdomen, and extremities were normal. Table 1 lists the laboratory findings. Hemoglobin, white blood cell count, and urinalysis were normal. The specific gravity and osmolarity of a random urine specimen were 1.001 and $61 \mathrm{mOsm} / \mathrm{kgH}_{2} \mathrm{O}$, respectively. The serum sodium was $152 \mathrm{mEq} / 1$, potassium $4.4 \mathrm{mEq} / 1$, chloride $110 \mathrm{mEq} / 1$. The plasma osmolarity was $301 \mathrm{mOsm} / \mathrm{kgH}_{2} \mathrm{O}$. The renal functions assessed by endogenous creatinine clearance was normal, but urinary excretion rate of phenolsulfonphthalein (PSP) was decreased. The plasma levels of pituitary hormones were within normal limits, with the exception of plasma ADH which was as high as $7.2 \mathrm{pg} / \mathrm{ml}$.

Computed tomography of the brain revealed no remarkable findings. Intravenous pyelogram showed a marked hydronephrosis and dilatation of the bladder and ureters but no evidence of reflux.

The results of the water deprivation test are shown in

From the Third Department of Internal Medicine, Fukushima Medical College, Fukushima, *the Physical Health Care Center, Fukushima University, Fukushima, and **the Pathology and Cytology Laboratory, BML, Tokyo

Received for publication June 10, 1992; Accepted for publication December 11, 1992

Reprint requests should be addressed to Dr. Hajime Ishii, the Third Department of Internal Medicine, Fukushima Medical College, 1 Hikariga-oka, Fukushima 960-12, Japan 


\section{IsHII et al}

Fig. 1. During a 2.5-hour water deprivation test the urine osmolarity was practically unchanged, while the plasma osmolarity rose from 293 to $312 \mathrm{mOsm} / \mathrm{kgH}_{2} \mathrm{O}$, and weight loss was $2.1 \mathrm{~kg}$. Following the test, 5 units of pitression were given intramuscularly. Over the next 1.5 hours, the urine osmolarity rose only from 51 to $61 \mathrm{mOsm} / \mathrm{kgH}_{2} \mathrm{O}$, and the plasma osmolarity rose from 312 to $321 \mathrm{mOsm} / \mathrm{kgH}_{2} \mathrm{O}$.

Table 1. Laboratory Findings

\begin{tabular}{|c|c|c|c|}
\hline \multicolumn{2}{|c|}{ Erythrocyte sedimentation rate } & \multicolumn{2}{|c|}{ Renal function test } \\
\hline & $6 \mathrm{~mm} / \mathrm{h}, 18 \mathrm{~mm} / 2 \mathrm{~h}$ & Ccr & $121.5 \mathrm{ml} / \mathrm{min}$ \\
\hline \multicolumn{2}{|l|}{ Blood cell count } & PSP (15 min) & $20.7 \%$ \\
\hline leukocytes & $6,800 / \mathrm{mm}^{3}$ & \multicolumn{2}{|l|}{ Osmolarity } \\
\hline erythrocytes & $4.45 \times 10^{6} / \mathrm{mm}^{3}$ & urine & $61 \mathrm{mOsm} / \mathrm{kgH}_{2} \mathrm{O}$ \\
\hline hemoglobin & $14.9 \mathrm{~g} / \mathrm{dl}$ & plasma & $301 \mathrm{mOsm} / \mathrm{kgH}_{2} \mathrm{O}$ \\
\hline hematocrit & $43.3 \%$ & \multicolumn{2}{|l|}{ Urinalysis } \\
\hline platelets & $31.2 \times 10^{4} / \mathrm{mm}^{3}$ & protein & $(-)$ \\
\hline \multicolumn{2}{|l|}{ Serum } & glucose & $(-)$ \\
\hline $\mathrm{Na}$ & $152 \mathrm{mEq} / \mathrm{l}$ & erythrocyte & $(-)$ \\
\hline $\mathrm{K}$ & $4.4 \mathrm{mEq} / 1$ & \multicolumn{2}{|c|}{ Endocrinological examination } \\
\hline $\mathrm{Cl}$ & $110 \mathrm{mEq} / 1$ & $\mathrm{ACTH}$ & $39 \mathrm{pg} / \mathrm{ml}$ \\
\hline $\mathrm{Ca}$ & $8.8 \mathrm{mg} / \mathrm{dl}$ & $\mathrm{GH}$ & $0.3 \mathrm{ng} / \mathrm{ml}$ \\
\hline$P$ & $4.2 \mathrm{mg} / \mathrm{dl}$ & FSH & $12 \mathrm{mIU} / \mathrm{ml}$ \\
\hline GOT & $15 \mathrm{IU} / 1$ & LH & $4.8 \mathrm{mIU} / \mathrm{ml}$ \\
\hline GPT & $14 \mathrm{IU} / \mathrm{l}$ & PRL & $10 \mathrm{ng} / \mathrm{ml}$ \\
\hline LDH & 377 IU/1 & TSH & $1.7 \mu \mathrm{U} / \mathrm{ml}$ \\
\hline ALP & $250 \mathrm{IU} / 1$ & $\mathrm{ADH}$ & $7.2 \mathrm{pg} / \mathrm{ml}$ \\
\hline BUN & $10 \mathrm{mg} / \mathrm{dl}$ & & \\
\hline Creatinine & $0.8 \mathrm{mg} / \mathrm{dl}$ & & \\
\hline Uric acid & $5.5 \mathrm{mg} / \mathrm{dl}$ & & \\
\hline Total protein & $7.3 \mathrm{~g} / \mathrm{dl}$ & & \\
\hline Albumin & $4.3 \mathrm{~g} / \mathrm{dl}$ & & \\
\hline
\end{tabular}

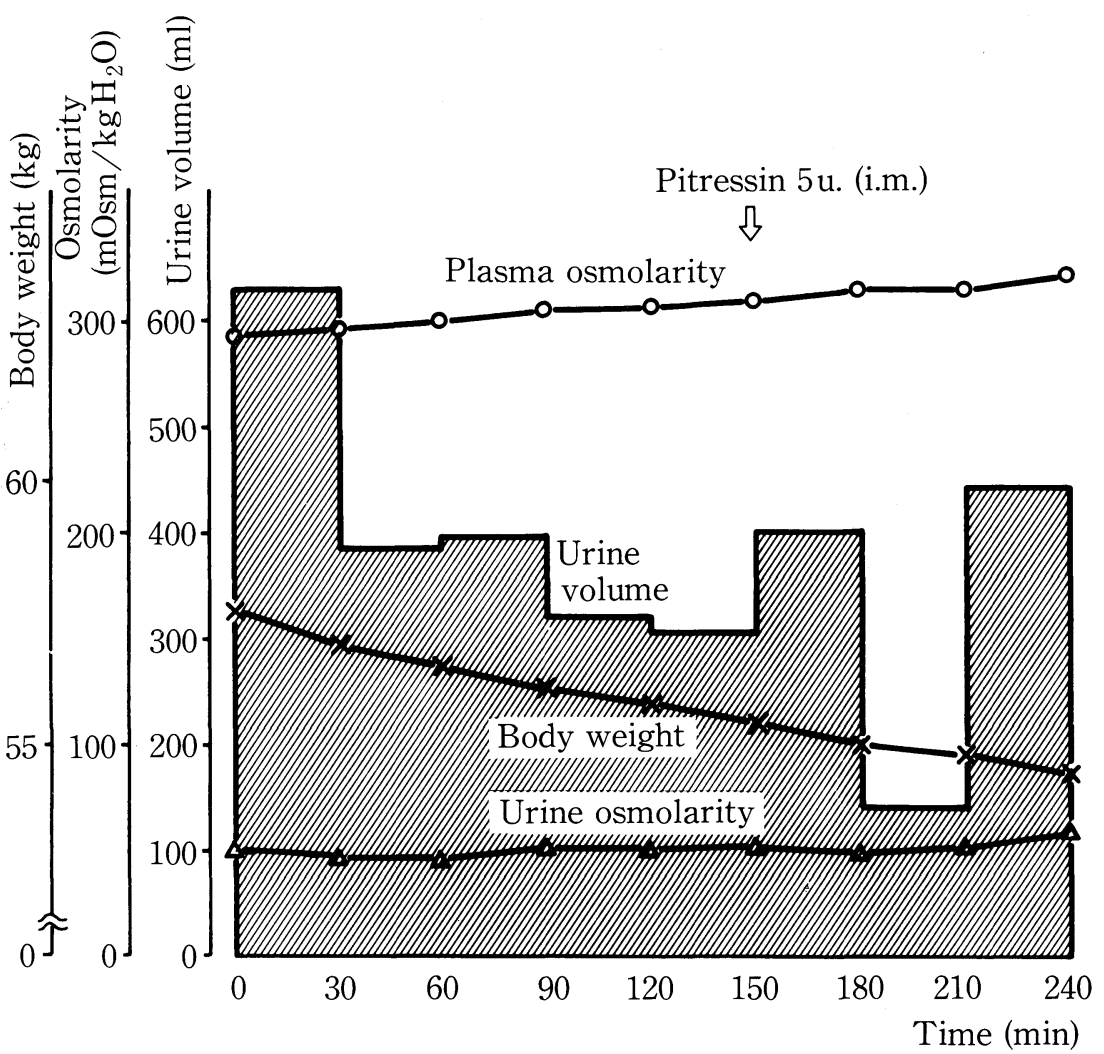

Fig. 1. Water deprivation test. Administration of pitressin elevated the urine osmolarity from 51 to $61 \mathrm{mOsm} / \mathrm{kgH}_{2} \mathrm{O}$. 


\section{An Adult Case with Congenital NDI}

Figure 2 shows the results of a hypertonic saline infusion test. Urine volume did not change after either the saline infusion $(2.5 \%$ saline, at a rate of $0.25 \mathrm{ml} / \mathrm{kg}$ per min, for $45 \mathrm{~min}$ ) or 5 units of intramuscular pitressin. After the administration of pitression, the urine osmolarity rose only slightly from 85 to $94 \mathrm{mOsm} / \mathrm{kgH}_{2} \mathrm{O}$, but urinary excretion of cyclic AMP (cAMP) did not respond to the agent. These results were consistent with nephrogenic diabetes insipidus.

After informed consent was obtained, the patient underwent a percutaneous renal biopsy under an echographic guide. The light microscopic examination of the specimen revealed that the glomeruli were almost intact, but an area of the epithelial cells between the distal tubules and collecting duct was atrophic; the cell height was lower and the duct space was relatively enlarged (Fig. 3). Arterioles and capillaries appeared intact.

Electron microscopic studies of the renal tissues showed that there was neither cell proliferation nor sclerosis in the glomeruli. However, the glomerular basement membrane (GBM) adjacent to the mesangial region was wrinkled and irregularly thickened (Fig. 4). The foot-processes of the epithelial cells were well preserved. In the proximal tubule, the brush-borders were decreased in number and shortened in length. The mitochondria of the proximal tubules were miniaturized and rounded (Fig. 5). In the distal tubules cell necrosis was seen occasionally, and the basement membrane was thickened.

After the completion of these studies, therapy with oral administration of trichlormethiazide was started with an initial daily dose of $1 \mathrm{mg}$. The daily dose of this agent was finally increased to $4 \mathrm{mg}$, which resulted in a reduction of daily urine volume from an average of 14,700 to $11,400 \mathrm{ml} / 24$ hour with a concomitant increment in urine osmolarity as well as a decrement in plasma osmolarity, as shown in Fig. 5. Hypokalemia possibly due to trichlormethiazide was not observed during the administration of the drug. However, since the daily urine volume was not decreased sufficiently with this drug, therapy with triamterene was superimposed on the chlorothiazide with the initial daily dose of $100 \mathrm{mg}$ and thereafter $200 \mathrm{mg}$. With this therapy, daily urine volume was reduced to about $6,000 \mathrm{ml} / 24$ hour on average, and urine osmolality was increased to $80-$ $100 \mathrm{mOsm} / \mathrm{kgH}_{2} \mathrm{O}$ (Fig. 6). Symptoms such as polydipsia and polyuria disappeared on this regimen. The patient was discharged on August 1, 1991. He was advised to

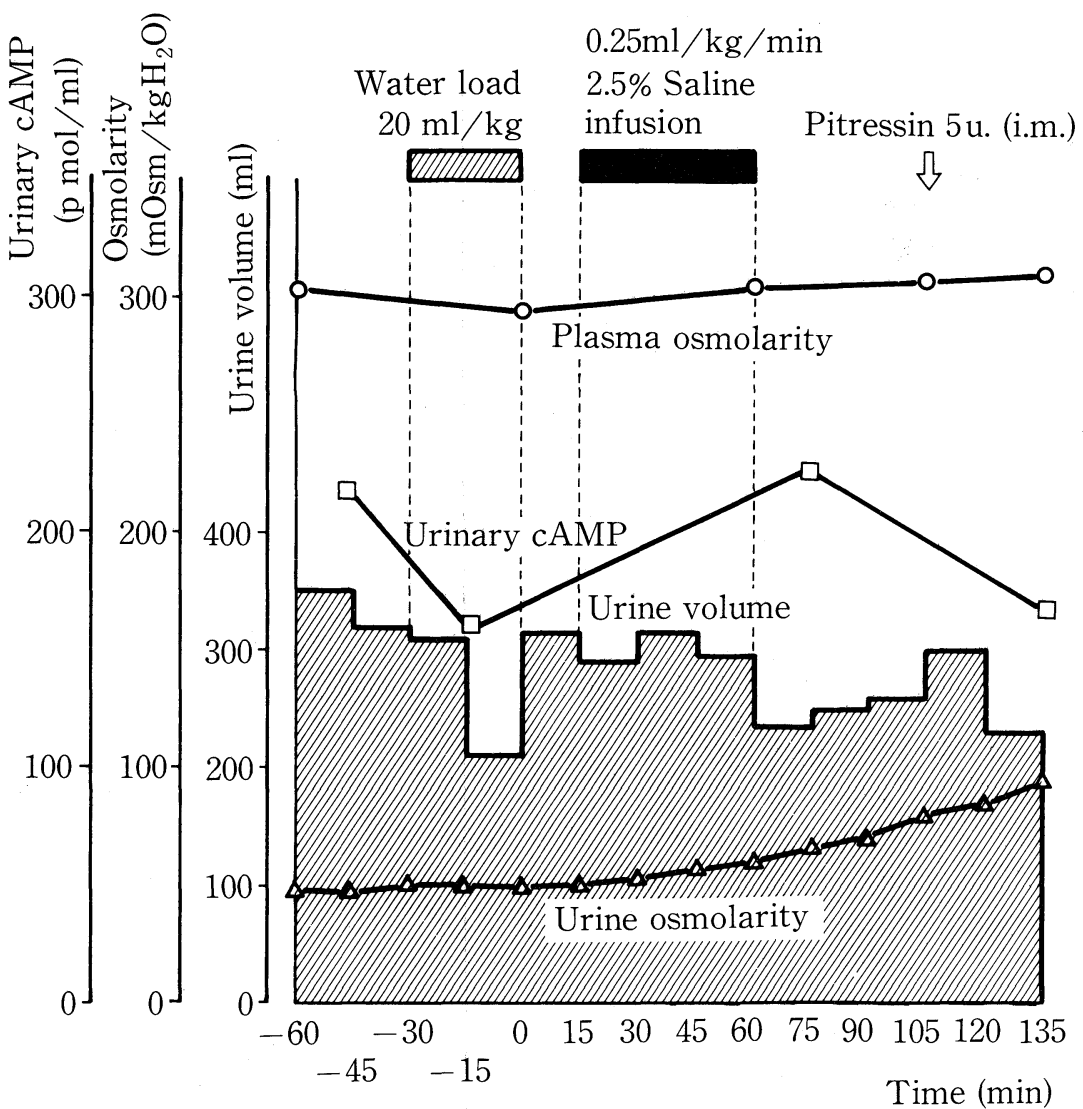

Fig. 2. Hypertonic saline infusion test. Administration of pitressin did not reduce the urine volume. 


\section{IsHII et al}

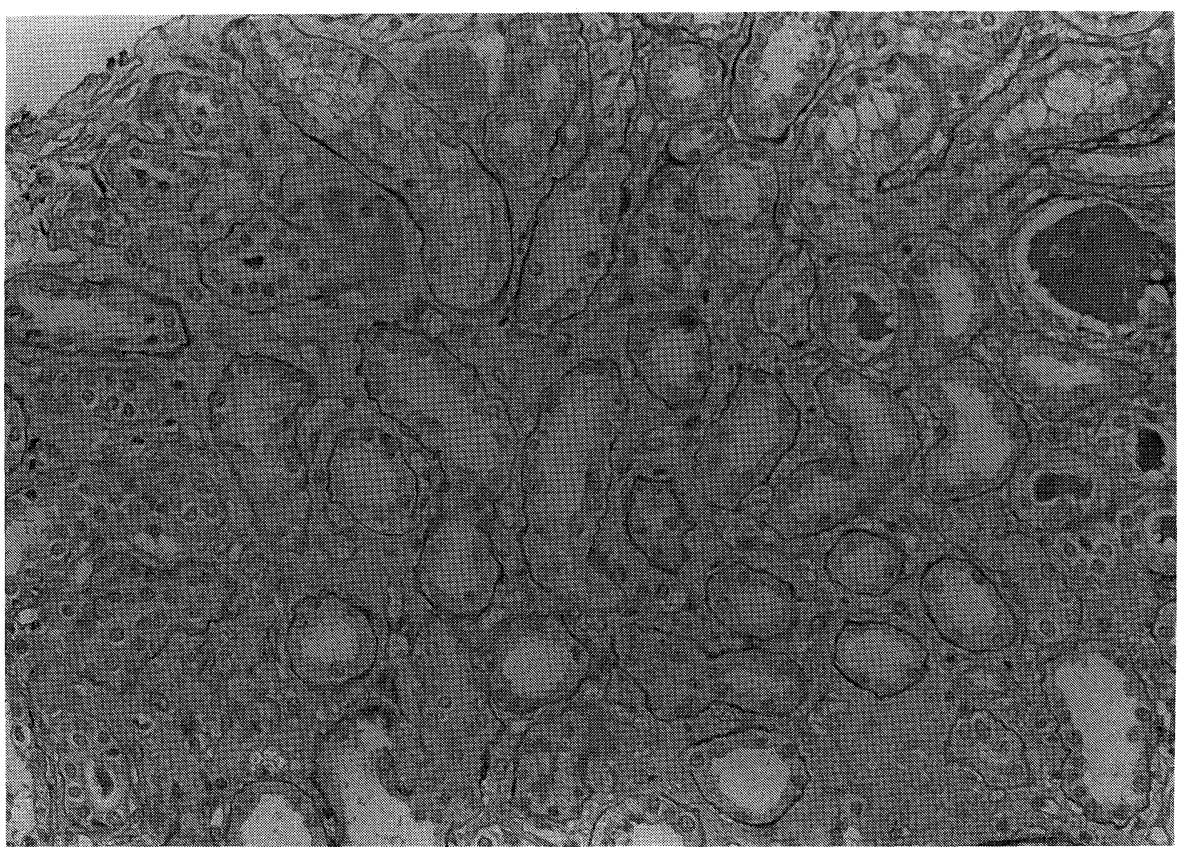

Fig. 3. Light microscopic findings of the renal specimen, showing atrophied epithelial cells between the distal tubules and collecting duct (HE stain, $\times 200$ ).

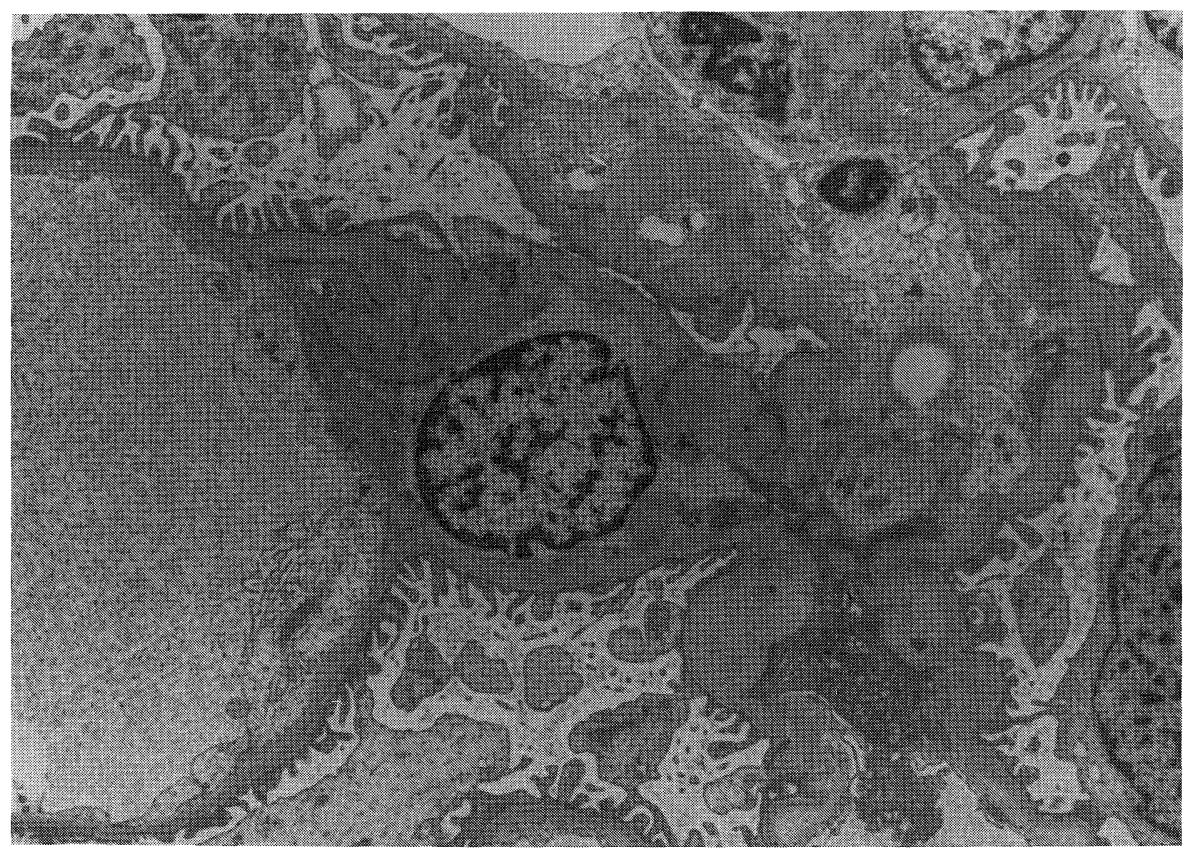

Fig. 4. Electron microscopic findings of the glomerular basement membrane adjacent to the mesangial region, showing wrinkled and irregularly thickened $(\times 5,520)$.

maintain a low salt diet and he received treatment with chlorothiazide and triamterene.

\section{Discussion}

The diagosis of NDI in our patient was made mainly on the basis of the response to a water deprivation test and lack of response to exogenous vasopressin. Symptoms related to NDI occurred at 2 months of age, indicating that the disorder is congenital. In addition, although NDI is usually transmitted as a sex-linked recessive disorder (2), sporadic cases have been reported $(3,4)$. 


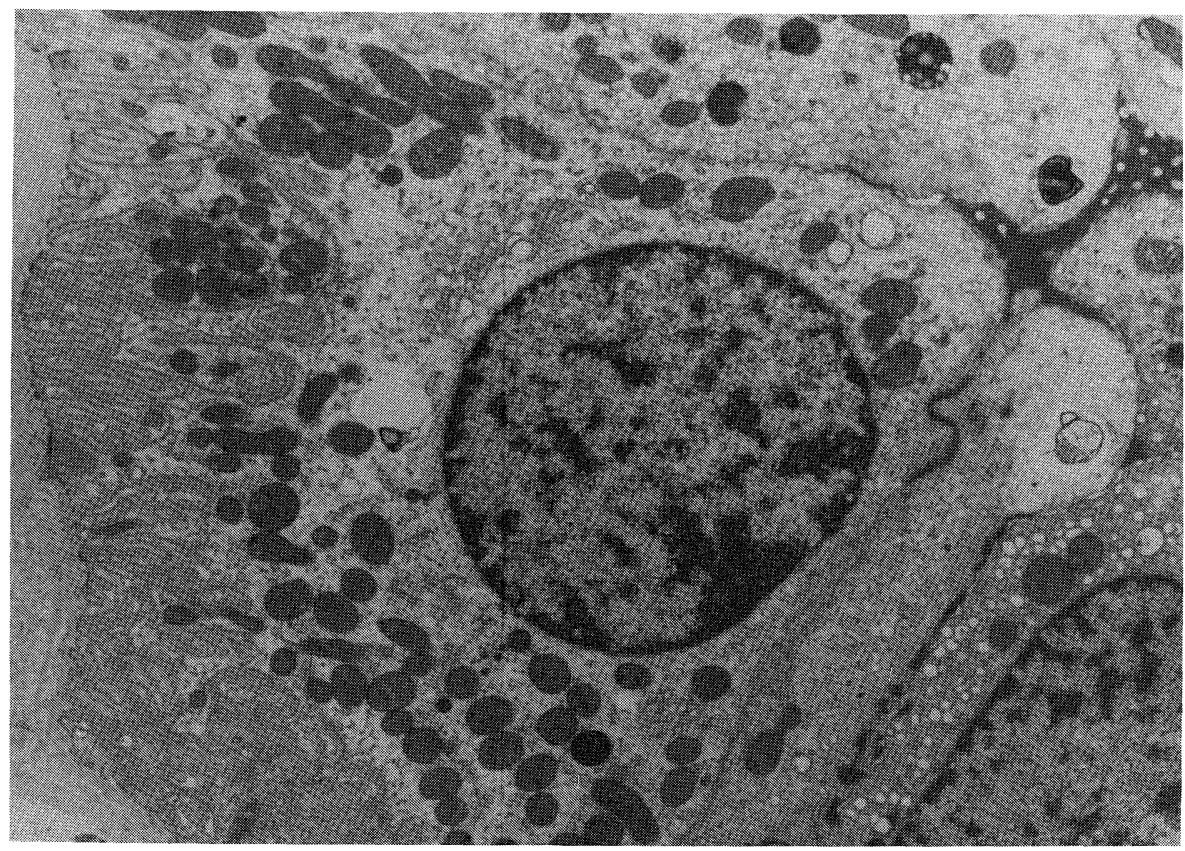

Fig. 5. Electron microscopic findings of the proximal tubules, showing decreased and shortened brush-borders. The mitochondria were miniaturized and rounded $(\times 9,660)$.

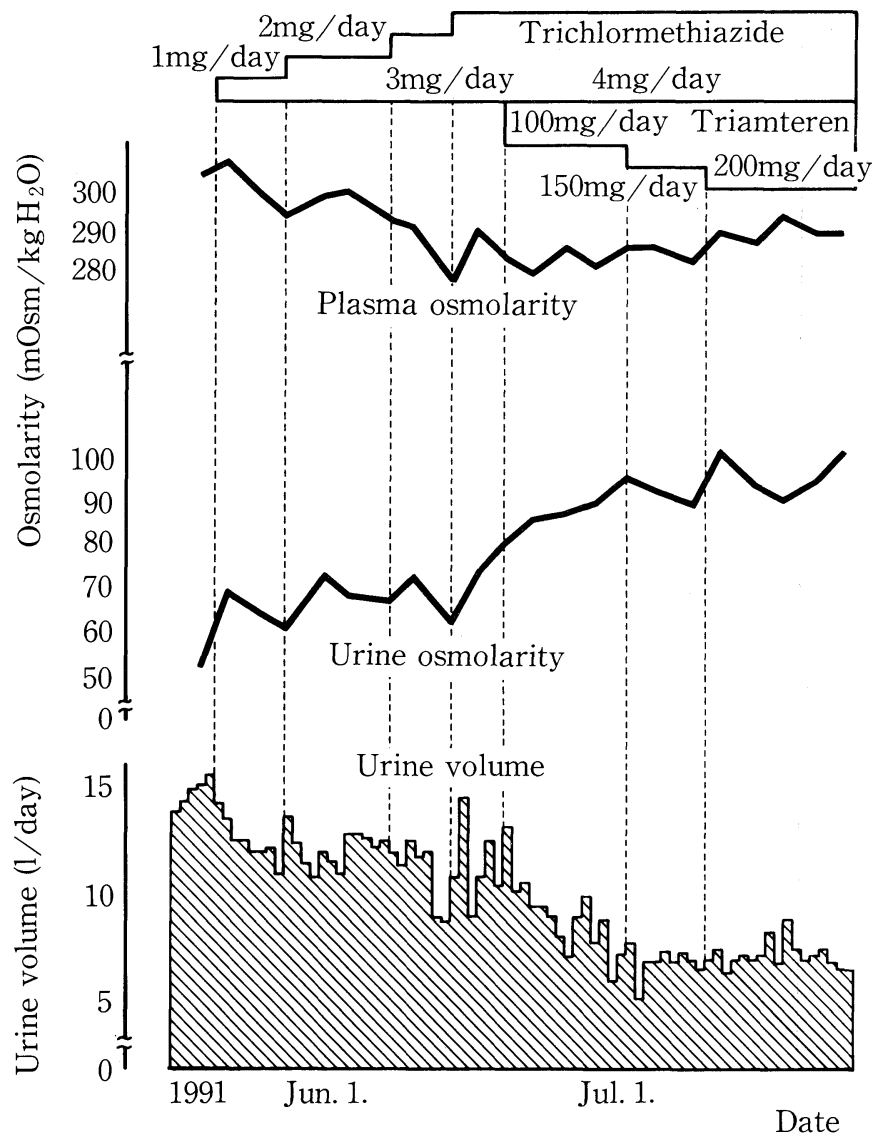

Fig. 6. Clinical course. Daily urine volume was reduced from an average of 14,700 to $11,400 \mathrm{ml} /$ day by $4 \mathrm{mg}$ of trichlormethiazide. A further decline in urine volume $(6,000 \mathrm{ml} /$ day $)$ was attained by trichlormethiazide combined with triamterene.
The present case also seems to be a sporadic case, because there was no family history of NDI.

Abelson reported a 7-month-old child with congenital NDI, in whom the fine structure of the kidney was described in detail (5). The author (5) noted that in both proximal and distal tubules, mitochondria contained concentric ringed structures, and that many mitochondria had myelin figures associated with their outer membranes. It was also reported in these studies that in addition to the tubular changes, the glomerular ultrastructure had a predominantly fetal configuration which would seem unusual in infants. In the present patient, the light and electron microscopic examinations of biopsied specimen of the kidney mainly revealed decreased brush-borders of proximal tubules and almost intact glomeruli. Presently, the mechanism underlying the differences in these structural changes is not clear. Also unknown is whether the tubular changes of our patient is the primary cause of NDI or a secondary damage due to prolonged NDI. It seems likely that such tubular changes might have contributed to the manifestation of severe polyuria, from the physiological point of view that mitochondria in the proximal tubules supply the energy for active transport of sodium to play a role in sodium and water reabsorption in the kidney (6).

There is still no satisfactory treatment for NDI. One of the recommended regimens is a low-sodium diet (7) coupled with diuretic agents. These include thiazide and potassium-sparing diuretics. Thiazides act in NDI primarily by inducing sodium loss and extracellular volume depletion, and enhancing proximal tubular fluid 
reabsorption (8). In our patient, treatment with trichlormethiazide resulted in reducing the daily urine volume, although the decrement in urine volume was not extensive. Alon and Chan reported effective therapy with hydrochlorothiazide coupled with amiloride (9). Our patient was thus treated with the thiazide combined with potassium-sparing diuretic triamterene. This combination therapy decreased the daily urine volume more effectively than did the thiazide alone, suggesting that the hydrochlorothiazide-triamterene regimen is superior to hydrochlorothiazide alone in the treatment of congenital NDI.

\section{References}

1) Williams RH, Henry C. Nephrogenic diabetes insipidus. Transmitted by females and appearing during infancy in males. Ann Intern Med 27: 84, 1947.

2) Bode HH, Crawford JD. Nephrogenic diabetes insipidus in North America. The Hopewell Hypothesis. New Engl J Med 280: 750,
1969

3) Anand SK, Kogut MD, Lieberman E. Persistent hypernatremia due to abnormal thirst mechanism in a 13-year old child with nephrogenic diabetes insipidus. J Pediatr 81: 1097, 1972.

4) Zimmerman D, Green CO. Nephrogenic diabetes insipidus-Type 2: defect distal to the adenylate cyclase step. Pediatr Res 9: 381, 1975.

5) Abelson H. Nephrogenic diabetes insipidus. A study of the fine structure of the kidney in a seven-month-old male. Pediatr Res 2: 271, 1968.

6) Fujita H, Fujita T. Textbook of Histology Part 2. Igakushoin, Tokyo, 1985, p. 183.

7) Blalock T, Gerron G, Quiter E, Rudman D. Role of diet in the management of vasopressin-responsive and -resistant diabetes insipidus. Am J Med 30: 1070, 1977.

8) Bichet DG, Levi M, Schrier RW. Polyuria, dehydration, overhydration. in: The Kidney, Physiology and Pathophysiology (1st ed.), Seldin DW, Giebisch G, Eds. Raven Press, New York, 1985, p. 951.

9) Alon U, Chan JCM. Hydrochlorothiazide-amiloride in the treatment of congenital nephrogenic diabetes insipidus. Am J Nephrol 5: 9,1985 . 